\section{Communing with bees: A whole-of-community approach to address crisis in the Anthropocene}

\author{
Jennifer Marshman * \\ Wilfrid Laurier University
}

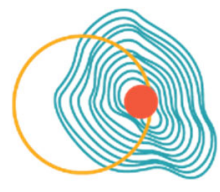

PLACE-BASED FOOD SYSTEMS CONFERENCE: Making the Case, Making it Happen August 9-10th, 2018

Submitted November 30, 2018 / Revised January 11 and January 28, 2019 / Accepted January 28, 2019 /

Published online May 16, 2019

Citation: Marshman, J. (2019). Communing with bees: A whole-of-community approach to address crisis in the Anthropocene. Journal of Agriculture, Food Systems, and Community Development, 9(Suppl. 1), 87-110. https://doi.org/10.5304/jafscd.2019.091.029

Copyright (C 2019 by the Author. Published by the Lyson Center for Civic Agriculture and Food Systems. Open access under CC-BY license.

\begin{abstract}
We are currently facing myriad socio-ecological crises, from global climate change to resource depletion to the loss of dozens of species every day. Despite a longstanding and impassioned environmental movement, these problems persist and are worsening. The extent and degree of human-induced change on the planet is significant enough to have placed us in a new geological age: the Anthropocene. Three perspectives are engaged as a way to understand this new era and address our fractured human-nature relationship: (1) political ecology, (2) the ecological humanities, and (3) the informal economy. An exploration of intersecting themes leads to the start of a new theoretical contribution, which manifests at the
\end{abstract}

* Jennifer Marshman, Department of Geography and Environmental Studies and the Laurier Centre for Sustainable Food Systems, Wilfrid Laurier University; 75 University Avenue West; Waterloo, Ontario N2L 3C5 Canada; +1-519-500-2349; jmarshman@gmail.com convergence of theories: a "whole-of-community" approach. This whole-of-community approach is one that is concerned with both inter-human and interspecies relationships to move us towards communities that are place-based, integrated, participatory, and grounded in eco-social justice and equity. Pollinating bees are used as an illustrative example of how to achieve this vision. Bees can be both a bridge and gateway. As a bridge, they can provide a way of (re)connecting human and nonhuman nature and as a gateway, they can guide humans to a deeper understanding and connection with urban natures. Reconciling humans with the rest of the biotic community through place-based initiatives is possible by fundamentally and radically expanding our current framing of the concept of community.

\section{Keywords}

Pollinators, Political Ecology, Community, Ecological Humanities 


\section{Introduction}

A dualistic and dysfunctional human-nature relationship that fails to recognize humans as nature, rather than humans in nature, has resulted in many of the socio-ecological crises that significantly impact and threaten food systems and the planet (Gaston, 2010; Plumwood, 2002; Gibson, Rose, \& Fincher, 2015). Despite awareness of these issues, they still exist and are worsening: "forests are shrinking, water tables are falling, soils are eroding, wetlands are disappearing, fisheries are collapsing, rangelands are deteriorating, rivers are running dry, temperatures are rising, coral reefs are dying, and plant and animal species are disappearing" (as cited in Hawken, Lovins, \& Lovins, 2013, p. 309). These insights are not new -in fact, this quote comes from the Worldwatch Institute's State of the World Report from two decades ago (Brown et al., 1997).

The current "biodiversity crisis" (Gaston, 2010 , p. 134) can be traced to a fractured humannature relationship that reflects the dominant, anthropocentric (human-centered) bias in Western ecological thought (Gibson et al., 2015; Myers, 2005; Plumwood, 2002). Political ecology provides a useful theoretical framing to view the relationship between humans and the rest of nature. This is because political ecology addresses the power imbalances at the root of environmental issues where the current power laden conditions often serve the "elite at the expense of the marginalized" (Heynen, Kaika, \& Swyngedouw, 2006, p. 6). Through this theoretical lens we can begin to understand that some of the most pressing ecological issues stem from an imbalance in socio-ecological power structures in which some humans are perceived as superior to other people and species. A second perspective, the ecological humanities, presents a complementary framework to political ecology in that it challenges this perceived exceptionality of humans (Rose et al., 2012). This helps us to engage with both human and interspecies power imbalances that exacerbate some of the most pressing socioecological crises (e.g., global climate change). A third theoretical framing, the informal economy, is applied as a way to illustrate the important contributions of the nonhuman co-creators of the environments in which we live, and that feed us.

Humans have been transforming local, regional, and global ecosystems for millennia (Ellis, Klein, Goldewijk, Siebert, Lightman, \& Ramankutty, 2010), but the modern extent and degree of human-induced change on the planet is significant enough to have placed us in a new geological age: the Anthropocene (Arias-Maldonado, 2015; Gibson et al., 2015). Moving beyond an over-simplified human-nature division requires recognizing the limitations of any approach that views nature purely for human utility (Soper, 1995). However one chooses to define nature, it ought to be considered "the habitat for the human species, the habitat for other species, and a significant entity in itself' (Arias-Maldonado, 2015, p. 6). We must critically examine our relationship with nature in an increasingly urbanizing world. In other words, "whatever nature may mean, we must determine in what way humanity fits into it" (Bookchin, 1992, p. 1). The fundamental problem with trying to separate humans and nature is that "the relationship is so close, the human influence on nature so large, the intertwining of the social and natural so deep, that it is not easy to extricate" one from the other (Arias-Maldonado, 2015, p. 47). In no way is this made more apparent than the fact that we have now entered the Anthropocene.

The Anthropocene-literally meaning the human epoch, or the age of humans-was a term first popularized by Crutzen \& Stoermer (2000). Recognition of the new epoch demonstrates that the "human species is becoming conscious of itself as a planetary force" and how we impact and are impacted by nature, at the largest and smallest scales (Blasdel, 2017, para. 9). There is often a gap between academic scholarship and "the real world" (Castree, 2014b, p. 235). The concept of the Anthropocene provides an intimate and relevant way to help address this gap by bringing together the "cerebral" and the "practical" along with the social and the natural (p. 235).

In 2008, after testing the Anthropocene hypothesis using geological criteria previously used to establish naming new epochs, the Anthropocene Working Group (AWG) was created by the International Commission on Stratigraphy (Castree, 2014a). In 2016, at the $35^{\text {th }}$ International Geological Congress, the AWG voted in support of the concept, agreeing that, "the Anthropocene 
concept ... is geologically real. The phenomenon is of sufficient scale to be considered as part of the Geological Time Scale" (University of Leicester, 2016, para. 3). Because of this decision by the AWG, the Anthropocene can no longer be considered a fringe concept, and yet, modern strategies have been unsuccessful at resolving the complex socio-ecological crises that we are faced with.

The term Anthropocene is used as a way to understand our human impact on Earth's systems, based in science. It is also used to politicize human impacts and the need for us to change our behavior in "new and unprecedented ways" in order to avoid ongoing environmental disaster (Bowden, 2017, p. 53). Although it's been nearly two decades since the advent of the term, the question remains: do the extensive human impacts on the ecosphere pose only an existential threat and cause for grief, or do they also provide a transformative opportunity? (Castree, 2014a; Cunsolo \& Landman, 2017; Moragues-Faus \& Marsden, 2017).

\section{Objectives}

This paper seeks to answer the following questions as part of a comprehensive review of the literature: How can a better theoretical framing of human-nature (dis)connections provide insights to address challenges related to living in the Anthropocene? How can our knowledge of food systems and the informal economy add to the theory needed to address these challenges, and what would that theoretical convergence look like?

To meet these objectives, this paper begins by describing a dualistic human-nature relationship common in Western ecological thought and a defining feature of the Anthropocene (Rademacher, 2015). In order to begin to adopt a reparative stance to our relationship with the Earth and stop seeing humans as separate from nature, this paper will engage with the following intersecting themes: the concept of hybrids (Castree \& Braun, 2001; Latour, 1993; Swyngedouw, 2006; Whatmore, 2006; Zimmer, 2010) and the theory of othering (Gibson et al., 2015; Heynen et al., 2006; Plumwood, 2002; Soper, 1995). We use the example of pollinating bees to illustrate the convergence of these themes through the notions of sharing and decentering humans in the concept of community.
The paper presents a conceptual model of the convergence of theories understood as a whole-ofcommunity approach and concludes with identified gaps and ways forward.

\section{Human-Nature Dualism}

Nature is one of the most complex words in the English language (Castree, 2014c; Soper, 1995). People define nature differently, and there remains an unresolved debate about how to define nature and what to include in the definition. Considering that most of the biosphere has been altered by human settlements and agriculture, and that human anthromes (defined below) now constitute threequarters of the terrestrial biosphere (Ellis, 2013), humans, human activities, and urbanization must be factored into any definition. In fact, there is no part of the biosphere untouched by human influence due to the global impacts of climate change (Arias-Maldonado, 2015).

Anthromes are "anthropogenic biomes [that] offer a new view of the terrestrial biosphere in its contemporary, human-altered form" (Ellis \& Ramankutty, 2008, p. 439). In other words, anthromes are comprised of the interactions between humans and nonhuman ecosystems. These include, but are not limited to, "mixtures of settlements, agriculture, forests and other land uses" (Ellis \& Ramankutty, 2008, p. 443). While conventional biome mapping remains a useful tool "based on climate, terrain, and geology," anthromes are a more accurate description of the terrestrial biosphere that does not separate humans from ecosystems (Ellis \& Ramankutty, 2008, p. 445). This is one way of recognizing that humans and nature are not distinct and bounded entities, but rather, they are inextricably tied by social and ecological fusions that create global flows and networks (Latour, 1993; Whatmore, 2002).

To advance the discussion on the human-nature relationship, we must return to the fundamental question: what is nature? Recognizing that there are concepts of nature outside of a Western worldview, I will focus on the Western perspective in view of its current dominance in ecological constructs (Arias-Maldonado, 2015). The word 'nature' first appeared in $7000 \mathrm{BCE}$ referencing plants (Arias-Maldonado, 2015) and common usage of 
the word describes everything that is not human (Latour, 1993; Plumwood, 2002; Soper, 1995). The term 'nature' is used to describe a complex, multilayered, multi-faceted, place-based, relational concept. Nature as a single entity is fairly unique to Western culture (Arias-Maldonado, 2015) and Williams (1980) cautions against using "a singular name for the real multiplicity of things and living processes" that constitute nature (p. 69).

References to nature in our daily lives are diverse, primarily through the media, marketing, and education (Castree, 2014c). These references are all part of "the social construction of nature" (Castree, $2014 a$, p. xxiii). In these various references, a line is often drawn between natural and built environments (Arias-Maldonato, 2015, p. 19). This separation becomes problematic when we begin to dissect what it means to be built. Everything that is built comes from materials found in the natural world, and the line between natural and artificial then becomes blurred. The following narrative helps to confront our current framing of the human-nature separation in this context:

Think about a forest. All around you there are trees rising up to form a dense canopy. In one of the trees is a bird's nest, twigs carefully woven together by a pair of birds, to produce the perfect cradle for their delicate cargo. As you walk on a little further into the forest, you encounter a river. Looking downstream, you notice a large pile of sticks and branches gathered together. But this is not a haphazard collection of driftwood. Rather, it's the purposeful work of a beaver, a lodge carefully constructed to provide shelter and warmth. All of what we've seen so far would be called nature, by most people. But if we move on a little further into the forest, and encounter a small clearing, and within it, a modest wooden hut, would this too be a part of nature? For many people, the bird's nest and the beaver's lodge are in, but the human hut is out. All three structures are built by their inhabitants, but only one is not natural. (van Dooren, 2016, 0:57')

This illustration of human versus nature helps us to understand humans within the domain of nature, rather than removed from it. This passage describes the ways that we are part of nature, showing the parallels between our homes and the homes of other animals. Soper (1995) asks "what is it exactly that makes human interactions with nature intrinsically devaluing?" (p. 19). Why is the human home less natural than the bird's nest or the beaver's lodge? Building on the observations of Jacobs (1961), who suggested that urban environments are "as natural as colonies of prairie dogs" (p. 443), Harvey (1996) claimed that "in a fundamental sense, there is nothing unnatural about New York City" (p. 186). What he means is that we cannot claim that everything is connected to everything else (as ecologists do), and then somehow exclude human settlements.

"First nature" is nature is its pristine form, untouched by human disturbance (Cronon, 1991; Marsden, 2012). This conceptualization of nature as a pristine wilderness strongly reinforces the human-nature dichotomy (Bennet \& Teague, 1999; Muir \& Cronon, 1997; Plumwood, 2002). Lefebvre (1966) made the distinction between the cities where we live, the countryside as the place of [agricultural] production, and nature as the place of escape. A pristine nature appeared in the Bible, first as an Eden and then as a wilderness to be feared (Muir \& Cronon, 1997). This view of nature understands humanity and development as autonomous from the environment and creates its own paradox: if the "romantic ideology of wilderness" is that nature must "be wild, then our very presence in nature represents its fall" and therefore the word itself "embodies a dualistic vision in which the human is entirely outside the natural" (Cronon, 1995, p. 16-17.) Wilson (1984) reveals how strongly we can dissociate ourselves from nature by drawing lines between areas with and without human activity, and by identifying human thought as something distinct and separate from nature:

The wildernesses of the world have shriveled into timber leases and threatened nature reserves. Their parlous state presents us with a dilemma, which the historian Leo Marx has called the machine in the garden. The natural world is the refuge of the spirit, 
remote, static, richer even than human imagination. (p. 11)

In this account, we are suspended "between the two antipodal ideals of nature and machine, forest and city, the natural and the artifactual, relentlessly seeking ... an equilibrium" (Wilson, 1984, p. 12). The dualism created by these distinctions is so entrenched that perceived differences are "familiar to the point of being common sense" (Castree, 2014c, p. 24). In other words, the humannature divide has been normalized in Western thought. Examples of Western, 21 $1^{\text {st-century sym- }}$ bols for nature in language include "environment, wilderness, biodiversity, animal, instinct, and ecosystem" (Castree, 2014c, p. 18). The removed quality of nature in these conceptualizations is incompatible with the concomitance of humans with the rest of nature.

"Second nature" is another paradigmatic view of nature: nature as a commodity (Cronon, 1991; Marsden, 2012; Smith, 2009). Second nature is a cultural, social, and political nature that has "all but absorbed first nature” (Bookchin, 1992, p. 13). Greenwashing, or green capitalism, is a "major strategy for ecological commodification, marketization and financialization which radically intensifies and deepens the penetration of nature by capital" (Smith, 2009, p. 17). Some argue that the commodification of nature began in earnest with the industrialization of the $19^{\text {th }}$ century Jaffee, 2007; Spash, 2015). In other words, the "appropriation of nature as resource for the production of culture" (Haraway, 1991, p. 292) has become a defining feature of Western-centric social structures. This view of nature as commodity forms the basis of the Limits to Growth theory by Meadows, Meadows, Randers, and Behrens (1972) that simulates exponential population growth with a finite amount of natural resources to support such growth, and more recently described as "peak everything" (Heinberg, 2010, p. 1; Meadows, Randers, \& Meadows, 2004). The "second nature" view also informs a productionist perspective for food systems, which identifies producing more as the way to reduce hunger and ensure that there is enough food for a growing global population (Fraser, 2013). This commodity-based view of nature can often be measured in terms of the market value of natural resources. In food systems, industrial agriculture is pitted against the organic and food sovereignty movements in a debate about which is better from a multitude of perspectives (Friedmann, 2005; Guthman, 2004). Even within the organic movement, there is concern about co-option of small-scale initiatives by industrial and global food corporations (Blay-Palmer, Sonnino, \& Custot, 2016). Co-optation of the organic movement is illustrative of nature as commodity - when food is treated like a commodity on the market, it is often to the detriment of other factors such as ecological health, human relationships, and social movements.

This view of nature as commodity or resource is a form of "reductive materialism" associated with modernity (Plumwood, 2009, p. 119). Nature as defined by its utility for humans is also called surface or shallow nature, or more commonly, ecosystem services (Arias-Maldonado, 2015; Soper, 1995; Waliczek \& Zajicek, 2016). This 'shallow nature' perspective lies at the heart of the conservation movement, which often has an underlying justification of protection based on the "importance in providing a scientific laboratory for naturalist studies... as a means of recreation and retreat, to the potential pharmacological value of its flora, or to the role it plays in maintaining genetic diversity" (Soper, 1995, p. 253). In other words, conservation is primarily concerned with managing human impacts in natural spaces through reduction of harm and efficiency of use. Use and enjoyment by future generations (of humans) is often the justification for this utility-oriented approach. Preservation, on the other hand, is about eliminating human impacts as much as possible, or the idealization of a pristine nature (Mare, n.d.; National Park Service, 2015). While conservation is critical to help mitigate anthropogenic planetary impacts, we must challenge the derivative notions of nature that dominate our language and education about nature by recognizing that humans and nature are not mutually exclusive (Castree, 2014c).

"Third nature" represents a new wave of "sustainable development and ecological modernization" (Marsden, 2012, p. 258). This new wave of green economy is understood as conventional (bioeconomy) and alternative (eco-economy), but both 
present "new arena(s) for capitalist penetration" (Kitchen \& Marsden, 2011, p. 757). The bio-economy includes the "transformation of nature at a more fundamental and genetic level" (Marsden, 2013, p. 218) through processes such as transgenic food crops, or crops that contain genetic material from an unrelated organism that has been artificially introduced. The eco-economy offers an alternative form of production-in food systems, alternatives are often grounded in agroecology and food sovereignty (Marsden, 2012).

As these approaches indicate, there has been a conceptual evolution from a conventional humancentered perspective to a more nuanced intertwining of society and nature, evidenced by a growing interest in ecological issues and healthy diets. Yet our language and understanding remain largely bipolar. The vast range of socio-ecological problems we face globally would suggest that we have still not embodied a true understanding of our role as part of the larger global ecosphere, and instead we continue to see ourselves as autonomous beings operating outside of nature (Cronon, 1995; Rademacher, 2015).

\section{Theoretical Framework}

In order to advance the discussion on reconciling human and nonhuman nature, my theoretical framework comprises three relevant perspectives: (1) political ecology, (2) the ecological humanities, and (3) the informal economy. The following section will indicate how each perspective adds to, and complements, the discussion about the human-nature relationship.

The politicization of our relationship with the environment is the foundation of political ecology scholarship (Robbins, 2012). Political ecology is an approach used to address and challenge the power imbalances (particularly in institutionalized forms) that create and maintain destructive environmental behaviors-also called the politicization of nature (Classens, 2015; Rademacher, 2015). By politicizing the human-nature relationship, we can "break from an image of a world where the human and the nonhuman are disconnected" (Robbins, 2012, p. 3). For example, from a Malthusian perspective, the rapidly growing human population is to blame for mass resource depletion and global change
(Ehrlich, 1968; Meadows et al., 1972). In other words, from this perspective, many modern socioecological crises are driven by an unchecked growth rate in non-industrialized countries. The primary problem with these Malthusian theories is that in fact, affluence and overconsumption of and from a very small number of people is what constitutes the highest resource (ab)use (Robbins, 2012). Political ecology grew from the need to challenge these views that "blame proximate and local forces" rather than identifying the broader, powerladen, normative systems at work in creating environmental problems (Robbins, 2012, p. 13).

Political ecology was a term first used in 1935, and later popularized by Blaikie and Brookfield (1987), when they identified that land degradation as an environmental challenge has social causes (Thone, 1935). They claimed that society-nature interactions must be better understood if solutions to socio-ecological problems are to be found (Blaikie \& Brookfield, 1987; Wolf, 1972). Alternatives to the dominant social conditions that perpetuate our current socio-ecological crises are those that are regenerative, participatory, multigenerational, and grounded in social justice and equity (Dahlberg, 1994). Urban political ecology is about radically democratizing "the organization of the processes through which the environments that we (humans and non-humans) inhabit" (Heynen et al., 2006, p. 2). This conceptualization emphasizes "equity and access" and addresses issues of power that are integral to political ecology scholarship (Agyeman \& McLaren, 2015, p. 4).

One way to approach this radical democratization is to challenge the idea that humans are superior to the rest of nature. This is a concept that is central to the ecological humanities, a theoretical perspective that was named in the late 1990s by Australian researchers and the first Environmental Humanities journal, published in 2012. The environmental humanities grew from the foundational work of the early $19^{\text {th }}$ - and mid-20th century environmental movement by attempting to "locate ecological problems in the behavior of human institutions, beliefs, and practices" (Emmett \& Nye, 2017, p. 3). In the first volume of the journal, the environmental humanities are described as enriching "environmental research with a more 
extensive conceptual vocabulary, whilst at the same time vitalizing the humanities by rethinking the ontological exceptionality of the human" (Rose et al., 2012, p. 1). The environmental humanities, therefore, grew and evolved out of the need for a more transdisciplinary and integrated approach to environmental issues and combined environmental concerns with social criticism (Rose et al., 2012; Emmett \& Nye, 2017).

Where political ecology provides a foundation that offers insights into some of the power dynamics at play in the human-nature relationship, the environmental humanities provide a different underpinning for such insights by decentering human agency (Rose et al., 2012). Defining nature as separate from humans is problematic, but rather than expand who is privileged, we must break down the dichotomy (Plumwood, 2002; Said, 1978; Soper, 1995). What is needed for this to happen is:

An ecocentric paradigm that displaces the anthropocentrism predominant in Western thinking about the natural world. Rather than positioning humanity at the center of the natural world, with human priorities as the only legitimate concern, ecocentricity decenters humanity and repositions us as interconnected and on an equal plane with other beings. Such an ecocentric perspective would ... engender a sense of responsibility and care. (Myers, 2005, p. 9)

The concept of connectivity-that humans and nonhuman nature are mutually constitutive-is integral to the environmental humanities (Rose \& Robin, 2004). Given the current environmental crisis globally, "we are no longer in the position of being able to sustain the idea that humans are separate from nature" (Gibson et al., 2015, p. 1). Disassembling the human-nature dichotomy and showing how nonhumans are co-producers of environments creates a mutuality that requires all urban actants to share democratic participation in humannature relationships (Zimmer, 2010).

Similar to the human-nature dichotomy, the formal versus informal economy is another example of how humans use opposition to understand complex issues. Inasmuch as the human-nature dichotomy is problematic, so is a dualistic construct of the economy. Using a strictly dichotomous framework risks failing to notice overlapping, semiformal activities (Hussain, 2011; Kamrava, 2004). Semiformality is understood as the areas of overlap between the formal and informal economy (Kamrava, 2004).

The informal economy is growing globally, and because of this, it has attracted the attention of many disciplines including geography, sociology, and economics (Godfrey, 2011; Hébert \& Mincyte, 2014; Portes \& Sassen-Koob, 1987). The concept of the informal economy has experienced several shifts, and many descriptions have emerged since its conception in the 1970s (Hart, 1973). Like the formal economy, the informal economy is the production, distribution, and consumption of goods and services, but untaxed and unprotected by labor laws the way formal economic activities are supposed to be (Chen, 2012; Hussain, 2011; Kamrava, 2004). Consensus on a comprehensive definition has proven difficult due to the vast array of informal economic activities spanning sectors in both industrialized and non-industrialized countries. Regardless of how one defines this process, failure to include informal economies in policy-making and analysis can lead to exclusion being built directly into programs. Better integration of informal economies into formal structures is a matter of "equity and social solidarity" (Becker, 2004, p. 4; Chen, 2007).

The informal economy additionally implies inherent power relations because the act of being informal implies structures of both dominance and resistance. As Foucault (1978) famously said, "where there is power, there is resistance" (p. 95). Foucault's view of resistance aligns nicely with the concept of the informal economy in that just as no single informality exists, he posits that there exists a "plurality of resistances, each of them a special case" (p. 96). In looking at power dynamics, the informal economy is directly concerned with alternativeness, which is inherently linked to resistance.

Informal economic activities can be categorized as follows: paid informal work, self-provisioning, and mutual aid (i.e., volunteer) (White, 2009; Williams \& Windebank, 2003). These categories provide a way to understand the human labor 
in informal economies, but there is another way to engage with informality: through nature. The economic contributions of nature are commonly referred to as ecosystem services. Ecosystem services are the socio-economic benefits that people derive from ecosystems, including provisioning, regulating, cultural, and supporting services (Atkins \& Atkins, 2016; Hassan, Scholes, \& Ash, 2005). These services are broadly defined as "something out there (ecosystems, nature, forests, watersheds...), provides things (resources, goods, products, services...), useful to people (health, livelihoods, fundamental life-support systems...), and this should be valued (often in monetary terms)" (Kull, Arnauld de Sartre, \& Castro-Larranaga, 2015, p. 122). As discussed previously, this view reinforces a utilitarian perspective, where the value of nature is based on its utility to humans, thus largely based on the market economy and the commodification of nature (Atkins \& Atkins, 2016; Hassan et al., 2005).

Nature's economy, however, is both formal and informal. For example, a Government of Canada survey focused on the economic benefits of nature for Canadians, indicating that more than CA $\$ 11.7$ billion was spent on nature-related activities in 1996, looking at GDP, jobs, and tax revenues (Environment Canada, Federal-ProvincialTerritorial Task Force on the Importance of $\mathrm{Na}$ ture to Canadians, 2000). Informally, engagement with urban nature, particularly in the form of urban gardening, has been shown to provide multiple benefits including improved overall well-being (Blum, 2016; Erickson, 2012; Gaston, 2010; Gentry, Anderson, Krause, Tucker, \& Tuddenham, 2015; Marcus \& Sachs, 2014; Shoemaker, 2006; Waliczek \& Zajicek, 2016). Ecosystem services have been increasingly quantified into the formal economy, and can be used as a justification for green development (Artmann, Bastian, Grunewald, 2017). But there are many ecosystem services whose benefits are largely unmeasured within the informal economy, including certain forms of biotic pollination (e.g., pollination by native bees of backyard and community gardens) (Andersson, Barthel, Ahrné, 2007; Matteson \& Langellotto, 2010).

As described, political ecology, the ecological humanities, and the informal economy are perspectives that provide a foundation for engaging with the human-nature relationship. Building on this foundation, I have identified three key intersecting themes that illustrate how these perspectives are linked.

\section{Theoretical Points of Intersection}

The previous descriptions show the complementarity between perspectives. I have identified several overlapping themes which the following sections will address in more detail: othering, hybrids, and sharing (Figure 1).

\section{Figure 1. Overlapping Themes of Political Ecology, the Ecological Humanities, and the Informal Economy Perspectives}



\section{Othering}

Othering is the active process of creating the other as a form of exclusion. The concept of the other is reliant on "broadly drawn dichotomies" (Mountz, 2009 , p. 238) inherent in any dualistic conceptualization (Haraway, 1991). Othering serves to both fetishize and dominate (not unrelated concepts), and the tendency to name things and places (such as humans and nature) as distinct and bounded entities creates "false models of reality" (Wolf, 1982, p. 41). In the human-nature relationship, othering allows people to affirm their own dominant status by identifying and naming difference (Canales, 
2000; Jackson, 2012). In the case of nature, a utilitarian perspective serves to other nature by making it inanimate, thus creating an "impediment to the emergence of more ecological and ... sustainable models of production and consumption" (Bennett, 2010, p. ix).

The otherization of nature provides a convenient platform from which to extract and abuse resources and creates a "remoteness [that] negates responsibility" (Plumwood, 2002, p. 16). In other words, "by longing for the pure and untouched wilderness spaces where they do not live, people tend to disavow any responsibility for the heavily urbanized environments in which they actually live" (Castree \& Braun, 2001, p. 26). Holding ourselves separate and apart from nature allows us to "evade responsibility for the lives we actually lead" (Cronon, 1995, p. 17). Dualistic language remains problematic, since discussions referring to humans in nature or humans as nature inherently divide and separate the two into two distinguishable entities (Cronon, 1991). A dominant worldview that privileges humans over other nature deprioritizes our dependency and interconnectedness with other living things and our environment (Plumwood, 2002; Soper, 1995).

Ecological concerns are "not independent of class, gender, ethnicity, or other power struggles," (Heynen et al., 2006, p. 10) where the other is "contained and represented by dominating frameworks" (Said, 1978, p. 40). Caniglia, Vallee, and Frank (2016) explore the relationship between different forms of oppression: "the oppression of various devalued groups in human societies is not independent and unrelated [to human-nonhuman oppression]; rather, the arrangements that lead to various forms of oppression are integrated in such a way that the exploitation of one group frequently augments and compounds the mistreatment of others" (p. 22). There is an interweaving thread of othering as a form of domination and control connecting human and nonhuman forms of oppression (Caniglia et al., 2016; Heynen et al., 2006; Plumwood, 2002). For example, food deserts, generally defined as a geographical area where access to healthy food is lacking or non-existent (Widener, 2018), were identified in the 1990s as being associated with poverty, class, and race (Blay-Palmer,
2016). Not surprisingly, where there is a lack of access to fresh food, there is also a lack of green space, pointing to a deprioritized status of both human and nonhuman nature in these settings (Alkon \& Agyeman, 2011). Urban food justice must be inclusive of the biotic community beyond humans, and resources must be understood in a "morethan-human relational context" (Cadieux \& Slocum, 2015, p. 14). Since human and nonhuman nature is co-constitutive, it is critical to recognize the related structural inequalities that necessitate both the urban food justice and the urban environmental movements (Classens, 2015).

Recognizing difference is not synonymous with othering. Humans have created the socio-ecological crises we are now faced with, which points to some of the ways we differ from other animals and species. Canales (2000) identifies two kinds of othering: inclusionary and exclusionary. Both are based in the context of power, but inclusionary othering practices "attempt to use power to create transformative relationships in which the consequences are consciousness raising, sense of community, shared power, and inclusion" (Canales, 2000 , p. 25). In contrast, exclusionary othering uses power for domination, subordination, and control (Canales, 2000). While both forms of othering confer an unequal power dynamic, inclusionary othering is about "reconceptualizing meanings and understandings" by expanding the "boundaries for defining self in relation to other" (Canales, 2000, p. 26). In theory, otherization needs to stop in all manner of human relations, as it is tied to "denials of dependency" that express the "failure to situate the human in ecologically embodied and socially embedded ways" (Plumwood, 2002, pp. 34, 27). In practice, using a form of inclusionary othering may help to dissemble the human-nature binary in creative and empowering ways grounded in sharing and reciprocity.

\section{Hybrids: The Role of Cities}

More than half of the global population is now living in cities, yet cities are still a relatively "new landscape for food studies" (Moragues-Faus \& Marsden, 2017, p. 283; United Nations, Department of Economic and Social Affairs, Population Division, 2014). More than 80 percent of the 
population of North America lives in cities, making urban spaces the environments that most people have contact with on a daily basis. In other words, cities are the places where the most human-nature interaction takes place. Therefore, fixing the planet necessarily means fixing cities (Agyeman \& McLaren, 2015; Fincher \& Iveson, 2015; Swyngedouw and Kaika, 2008; United Nations, Habitat III Secretariat, 2017; Waliczek and Zajicek, 2016). I use the term "interact" loosely because not all interactions are of equal quality. An interaction by definition requires some degree of mutuality or reciprocity, or "two elements engaging and influencing each other" (Gaston, 2010, p. 137). Interactions are two-way relationships. However, this is not the case with all human-nature interactions, particularly when nature is viewed from a utilitarian perspective (Gaston, 2010). In terms of the power dynamics, the relationship remains largely hierarchical, with humans assuming a controlling or dominating role to a subservient nature. The relationship is still two-way, but humans typically benefit at the expense of nonhuman nature, therein establishing a conspicuous lack of reciprocity.

Regardless of which conceptualization of nature is used, we must ask ourselves what "visions of nature, and what urban socio-ecological relations we wish to inhabit" (Swyngedouw and Kaika, 2008, p. 104). Political ecology problematizes a pristine nature outside of cities by attempting to integrate the seemingly disparate concepts of urban and natural (Classens, 2015; Cronon, 1995). Cities are "metabolic socio-ecological processes" connecting our "immediate environment to the remotest corners of the globe" (Swyngedouw \& Kaika, 2008, p. 98). Specifically, food systems "link rural and urban communities within a country, across regions and sometimes between continents" (Food and Agriculture Organization [FAO] and Resource Centres on Urban Agriculture and Food Security [RUAF] Foundation, 2015, p. 3). In this way, cities are fusions of social and physical resources that create global flows and networks (FAO and RUAF Foundation, 2015). In other words, development and capital accumulation are dependent on nature for their very existence, making nature and society inextricably "tangled" under the current capitalist system (Zimmer, 2010, p. 345). This pattern of production and consumption linking global environments to urban dwellers requires that environmental management begin in cities (Heynen et al., 2006). One way to begin the work of addressing the created inequalities that stem from anthropocentrism and to re-establish humans as nature is to view these relationships as hybrids (Latour, 1993; Swyngedouw, 1996; Whatmore, 2006; Zimmer, 2010).

Urban hybrids are mixtures of seemingly disparate entities and are understood as urban social natures or socio-natures (Braun \& Castree, 1998; Castree, 2014a; Latour, 1993; Swyngedouw, 1996; 1999). There is nothing purely social about a city, nor is there anything purely natural — they are liminal spaces comprised of what Haraway (1991) calls “cyborgs" (p. 291), or "couplings between organism and machine" (p. 150). Cities are often thought of as the antithesis of nature and epitomize hybridity. Hybrid mixtures are seen everywhere: "concrete alleys of trees ... urban drinking water and waste water..., [and] urban air that is polluted with different chemical compounds" (Latour, 1993, p. 10).

The food system is a global patchwork of hybrids across scales and modes of production. For example, rather than existing in isolation, concepts of conventional and alternative, and urban and rural, are relational rather than separate (MoraguesFaus \& Marsden, 2017). As an "intimate commodity"- -literally taken into the body (Winson, 1992, p. 4)-food and food production are perhaps the most significant points of engagement between humans and their environment. And yet the lack of necessity (and capacity) for many North American homes to provide food for themselves leads to a greater disconnect between people and the very environment needed to grow that food. Prior to the $19^{\text {th }}$ century, nearly all food in North America was local and seasonal (Waliczek \& Zajicek, 2016). Consumers often had direct contact with producers and good seasonal knowledge, until food preservation and transportation were modernized. Post-WWII eating out became common in North American households, alongside large scale uptake of packaged and processed foods. This industrialization of the food system resulted in reduced seasonality, as foods could be shipped long distances 
and stored for longer periods of time (Waliczek \& Zajicek, 2016).

Over the past couple of decades, eating locally or seasonally has been re-popularized, being baptized with the term "locavore" (Waliczek \& Zajicek, 2016, pg. 271). Some manifestations of the local food movement are urban farming, urban gleaning, community gardening, community supported agriculture, rooftop gardens, edible landscapes such as food forestry, institutional gardening, foraging, and home gardening (Waliczek \& Zajicek, 2016). In a rapidly urbanizing world, these manifestations indicate a desire to become more connected with our food and provide a pathway to reconnecting with our natural environment.

An estimated 15 percent of global food production happens in cities (Blum, 2016). Most industrialized nations rely largely on imported food products, and yet millions of urban residents are taking part in some form of urban agriculture (Grewal \& Grewal, 2012). The Resource Centres on Urban Agriculture and Food Security [RUAF] Foundation (n.d.) defines urban agriculture as "the growing of plants and the raising of animals within and around cities" (p. 1). There is a growing body of literature on the benefits of urban agriculture, including mitigating food insecurity, global climate change, the urban heat island effect, the various forms of malnutrition, and creating more sustainable and resilient communities (de Zeeuw \& Drechsel, 2015). Urban agriculture is not a new phenomenon-for as long as there have been cities, people have been growing food and raising animals within city limits. And in fact, today there are more than 800 million people practicing urban agriculture-or "urban own-growing"-globally, and the number is growing in North American cities (Blecha \& Leitner, 2014; Wolch \& Emel, 1998). These activities are happening in both formal (e.g., market gardens) and informal ways (e.g., "urban owngrowing"), and provide another form of hybridity by merging elements conventionally thought of as urban and rural, and from the natural and built environment (Blum, 2016, p. xvii).

\section{Sharing and the Commons}

With urbanization increasing along with its associated negative socio-environmental outcomes, how can urban landscapes be managed to minimize negative impacts? Marx (1867) spoke of the "enclosure of the commons" as a "parliamentary form of robbery" (p. 513). He was referring to the appropriation of land that "increase[d] the monopolies of farms, [and] raise[d] the prices of provisions" (Marx, 1867, p. 513). Harvey (2013) later called this the neoliberal capitalist "accumulation by dispossession," capturing the concept of unequal power distribution and confinement of agency that are foundational to the ecological humanities and political ecology scholarship (pp. 53-54).

A sharing paradigm is based on the ideas of mutuality and reciprocity. As co-creators of the environments we inhabit, our world and everything we need for survival are shared. It is possible to create more just, sustainable, equitable cities, both socially and ecologically (Gibson et al., 2015; McLaren \& Agyeman, 2015). A "sharing city" is "an advanced democratic city," and is "not one where even the poor own cars, but one where even the rich ride busses" (McLaren \& Agyeman, 2015, p. 4). Fairness and justice between species are also possible, through developing "ethical ontologies that make available richer and less reductive ways to individuate, configure, and describe the world that make the most of the non-human other" (Plumwood, 2002, p. 169). In other words, by recognizing and maximizing the real and potential contributions of both humans and nonhumans, we can create urban environments that are richer, more just, and equitable.

Harvey (2003) imagined the creation of a new urban commons where the right to the city is about the "right to make the city different" (p. 941). He stated that "if our urban world has been imagined and made then it can be re-imagined and re-made" (Harvey, 2003, p. 941). If "we individually and collectively make the city through our daily actions and ... engagements," (Harvey, 2003, p. 939) then we are capable of fundamentally changing our way of being in cities. By doing so, we can create more equity and use resources in more sustainable ways (Agyeman \& McLaren, 2017). Unfortunately, equity and justice are often an afterthought in urban creative processes (Agyeman \& McLaren, 2017). This is not dissimilar to the tendency of the social sciences to add nature in, rather than being critical 
about existing "social hierarchies and discursive conventions" (Whatmore, 2002, p. 23) that maintain nature's subordinated status.

Agyeman and McLaren (2017) describe cities as "the centrality of collaboration and sharing" (p. 24). Cities provide new, innovative opportunities for the kind of sharing that enhances trust and builds social capital. Sharing is already happening in cities in myriad ways: shared services, shared values, shared activities, and shared experiences (McLaren \& Agyeman, 2015). Cities can become places where "sharing resources fairly [and] nurturing the collective commons" (McLaren \& Agyeman, 2015, p. 9) are the standard. But is it possible to "construct a socially just city" (Harvey, 2003, p. 940) when cities have never been harmonious places, free from conflict? For cities to embrace a sharing paradigm, we must move past our obsession with consumption and ownership. This system change can best be done by "strategically combining re-invention and subversion," which "seek interlinked opportunities to enhance well-being, increase justice and equity, and spread participative democracy" (McLaren, 2015, para. 80).

Sharing, and the concept of the commons, intersect all three theoretical framings. From a political ecology perspective, sharing inherently bypasses issues of power imbalances and creates more just and equitable environments and communities. Sharing and commoning are forms of political collectivity that push back against exclusive capitalist power structures, an action that constitutes a form of resistance. Where the ecological humanities refute a human-centered worldview, informal food economies are pushing back against the industrialized and destructive food system.

I have provided an overview of how we might begin to understand the human-nature relationship through the intersecting themes of three perspectives. This is meant to provide a preliminary thought experiment about how these perspectives interact and how they can be used to engage with the literature. I have shown how understanding and linking the concepts of hybrids, othering, and sharing can help us to move beyond our binary thinking about the human-nature relationship. In moving past this binary thinking, we need to learn "new ways to live with the earth, to rework ourselves and our high energy, high consumption, and hyper-instrumental societies adaptively ... we will go onwards in a different mode of humanity, or not at all" (Plumwood, 2007, para. 1).

\section{The Convergence of Perspectives}

Teasing apart the human-nature relationship continues to elude academics and researchers, although the conversation is vibrant (Blay-Palmer, 2016; Bowden, 2017; Gibson et al., 2015; Heynen et al., 2006; Latour, 1993; Mitchell, 2018; Moragues-Faus \& Marsden, 2017; Plumwood, 2002; Swyngedouw $\&$ Kaika, 2008). Figure 2 shows the conceptual model of the convergence of perspectives in an attempt to capture some of the complexity of the relationship(s) between them.

This section begins with the result of the convergence of perspectives understood as a "wholeof-community" approach. To illustrate this convergence, pollinating bees provide both a bridge and gateway: as a bridge, they can provide a way of (re)connecting human and nonhuman nature, and as a gateway, they can guide humans to a deeper understanding and connection with urban natures.

\section{Whole-of-Community}

Gibson et al. (2015) describe community as a process: "being-in-common— that is, community — can no longer be thought of or felt as a community of humans alone; it must become a multi-species community that includes all of those with whom our livelihoods are interdependent and interrelated" (p. 10). Even though the concept of community is not synonymous with the concept of the commons, community can be viewed as commons. In other words, the community itself is a shared resource that benefits all community members. The challenge then is to enable and operationalize multispecies communities which reflect the "doctrine that humans share a profound identity with nonhuman nature" (Naess, 1989, p. 6, 17).

Bird (2016) reminds us of the etymology of "communitas," which simply means exchange of ourselves (p. 156). To build on the ideas of sharing and community, as described by the works of Marx (1867), Leopold (1949), Plumwood (2002), Naess (1989), Rose et al. (2012), and others, I propose that we find new ways to operationalize a whole- 
Figure 2. Conceptual Model of the Convergence of Perspectives

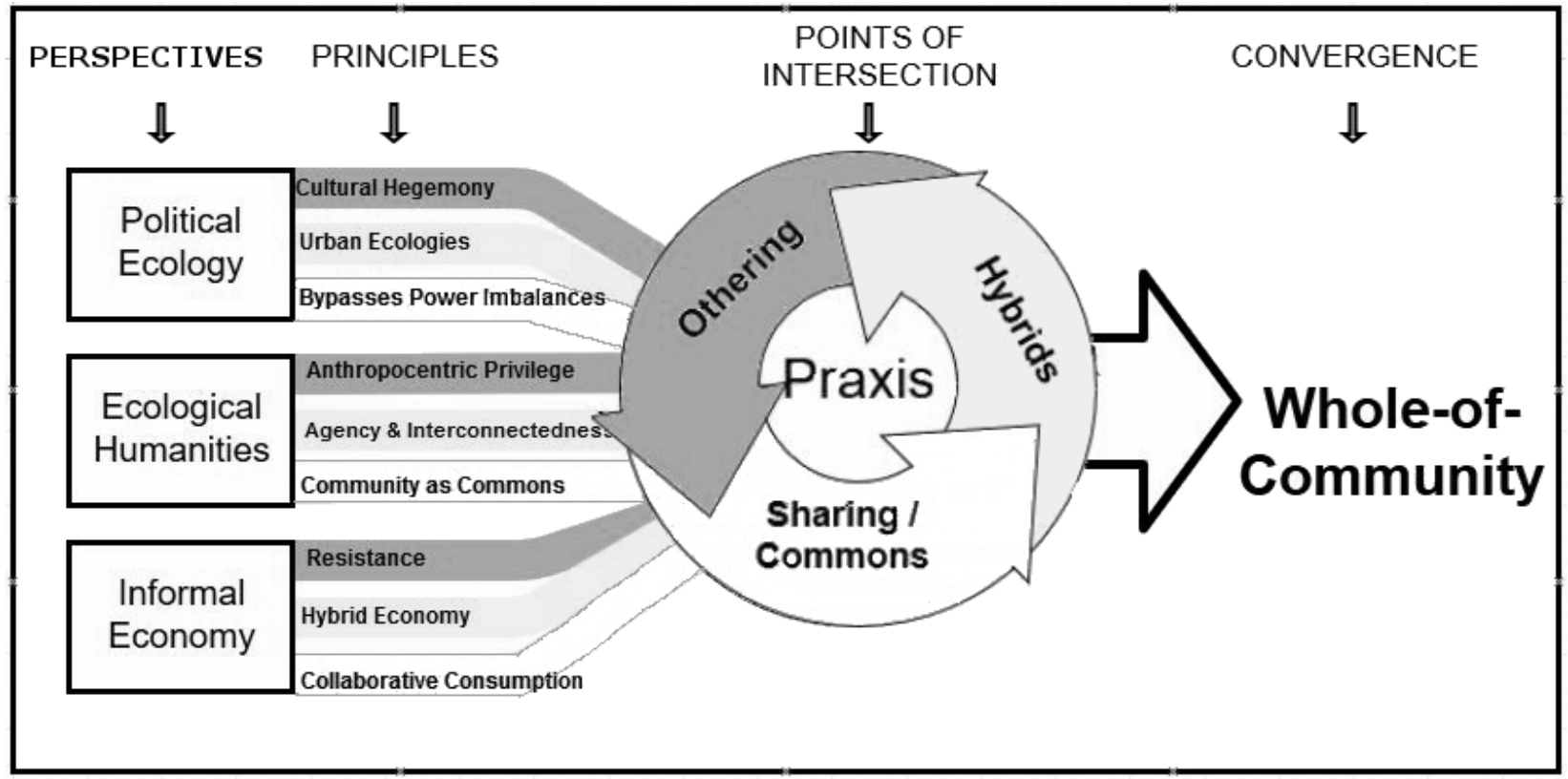

of-community (WOC) approach to living in urban settings. A new WOC approach will build on some of the principles of earlier conceptualizations of whole society or previously used whole community approaches, such as those used in emergency management and public health initiatives (BoelsenRobinson et al., 2015; Dube et al., 2010; Federal Emergency Management Agency [FEMA], 2011; Ewart-Pierce, Mejía Ruiz, \& Gittelsohn, 2016; Ollerenshaw, 2012).

Whole community strategies have been used in emergency management as well as to address illiteracy and obesity (Boelsen-Robinson et al., 2015; Ewart-Pierce et al., 2016; Ollerenshaw, 2012). This approach is recognized as a way to empower and integrate people from the community to strengthen social infrastructure and facilitate community resilience, particularly by building social capital (FEMA, 2011). An interspecies approach to building social capital_or what Carr (2004) calls "ecosocial capital" that is "concerned with both interhuman and interspecies relationships"- (p. 47) is missing from current whole community conceptualizations.

The call for a novel concept of community is not new. In A Sand County Almanac, Leopold (1949) called for an ethic that "enlarges the boundaries of the community to include soils, waters, plants, and animals" (p. 239). In other words, a "concept of community ... that would include the whole of the biotic community" (Gibson et al., 2015, p. 2). This concept of working toward connectivity means resituating humans in ecological terms; that is, addressing human-centered approaches in ways that recognize, embrace, and uphold the co-constitutive networks that humans are part of (Plumwood, 2002).

The "effective functioning of any ecosystem depends on the interactions that occur between species" (Gaston, 2010, p. 46). Leopold (1949) challenged the human-nature dichotomy with his concept of an ecological ethic, and he believed that environmental issues cannot be solved unless people feel they are part of the natural world, rather than mere visitors or observers. This idea is echoed in the work of Plumwood (2002), who identified the two central tasks of the ecological humanities as being (1) to resituate the human within the environment, and (2) to resituate nonhumans within cultural and ethical domains. Leopold's (1949) land ethic is described as a reflection of the existence of an "ecological conscience" which "in turn, reflects a conviction of individual responsibility for the health of the land" (p. 258). Merchant (1995) calls this a "partnership ethic," described as: 
A relationship between a human community and a nonhuman community that recognizes its connections to the larger world $\ldots$ in which humans act to fulfil both human needs and natures needs by restraining human hubris. (p. 158)

My WOC approach aims to disassemble destructive binaries and actively reassemble collaborative and inclusive communities in cities. This can begin with embracing the nonhuman as a part of the community by acknowledging that "the environment itself can suffer injustices" (MoraguesFaus \& Marsden, 2017, p. 278). This WOC approach will represent the ultimate hybrid, for it is a way of truly integrating urban socio-natures. Modern communitarianism has missed the mark by "invoking normative configurations of community, like the family, the neighbourhood and the nation, without examining the power relations they enact" (Whatmore, 2006, p. 151). Drawing on the "morethan-human" literatures (Braun, 2005; Cianchi, 2015) can augment the process of recognizing all living organisms as members and co-creators of urban environments. Including more-than-human agency in a WOC approach allows for the integration of the human-nature relationship "in ways that are not accessible if agency is restricted" (Cianchi, 2015, p. 34).

\section{Pollinators as Praxis}

Praxis is broadly defined as the unity of theory and practice. As co-creators of urban spaces, pollinating bees are important members of our urban communities as part of the socio-natural capital. From a theoretical perspective, bees present some interesting and relevant linkages between the themes identified in political ecology, the ecological humanities, and the informal economy. The commodification of pollination services is a form of othering that prioritizes human interests over the health and well-being of nonhuman nature (i.e., both bees and the flora that depend on them for reproduction). This hierarchy has created a division even between bee species where the financialization of the pollination services of the honey bee, Apis mellifera, is deemed more valuable than pollination services provided by other bee species, possibly at the expense of native species. Like many contributions to the informal economy, the everyday contributions of wild bees have become a "subordinated and dependent feature of capitalist development" (Chen, 2012, p. 3).

Pollinators provide an estimated $35 \%$ of global crop volume (Intergovernmental Science-Policy Platform on Biodiversity and Ecosystem Services [PBES], 2016) and pollinate an estimated 90 percent of flowering plants on Earth (Atkins \& Atkins, 2016; Ollerton, Winfree, \& Tarrant, 2011; Yang, 2006). Yet the value of pollination by wild bees has been "overlooked for centuries" (Klein et al., 2007, p. 307). In Canada, there are more than 1,000 species of biotic pollinators, including bees, wasps, flies, beetles, butterflies, moths, and birds, with 856 native bee species accounting for more than 70 percent of the biotic pollination (Seeds of Diversity, n.d.; Sheffield et al., 2017). Worldwide, pollination services are estimated at hundreds of billions of dollars annually (Atkins \& Atkins, 2016; Chaplin-Kramer et al., 2014). Yet, in an increasingly urbanizing world, the importance of urban spaces for pollinator habitat is still understudied (Baldock et al., 2015). Similar to the growing interest and body of research on urban natures, available studies indicate that any strategy addressing pollinators needs to address pollinators in urban spaces (Baldock et al., 2015; IPBES, 2016; Hall et al., 2017; Shephard, Vaughan, \& Black, 2008; Tonietto, Fant, Ascher, Ellis, \& Larkin, 2011).

As has been stated, bees can be both a bridge and gateway: as a bridge, they can provide a way of (re)connecting human and nonhuman nature, and as a gateway, they can guide humans to a deeper understanding and connection with urban natures. In recent years, there has been a significant uptake of urban beekeeping and an increase in pollinator research, especially on the European honeybee, Apis mellifera (Deveau, 2016; Lorenz \& Stark, 2015; Wright, 2017). Apis mellifera has become something of a charismatic micro-fauna or flagship species (Matteson \& Langellotto, 2010). Flagship species are defined as "popular charismatic species that serve as symbols and rallying points to stimulate conservation awareness and action" (Barua, Gurdak, Ahmed, \& Tamuly, 2012, p. 1458). The increased interest in Apis mellifera is largely driven by 
"the value of pollination services .... and contribution to human food supplies" (Hicks et al., 2016, p. 1).

Concerns for bees grew in response to the phenomenon called Colony Collapse Disorder (CCD) in Apis mellifera. CCD is defined as when entire managed colonies die off or disappear suddenly (Atkins \& Atkins, 2016; Kosek, 2011; Suryanarayanan \& Kleinman, 2016). In 2006/2007 approximately 10 percent of Apis mellifera colonies were entirely lost in the United States, with affected beekeepers losing 30 to 90 percent of their colonies, an event which resulted in the naming of the phenomenon (Atkins \& Atkins, 2016; Suryanarayanan \& Kleinman, 2016). With that said, reported cases of CCD have continued to decrease in recent years, although colony losses are still a concern (United States Environmental Protection Agency, 2018).

Even though Apis mellifera has become something of a stand-in for all pollinators, wild bees are more efficient pollinators of many plants and are responsible for the majority of pollination, especially in urban settings (Atkins \& Atkins, 2016; Pfiffner \& Muller, 2016). Apis mellifera is also not currently an endangered species, contrary to media messaging (City of Toronto, 2017). Instead, there are seven species of native bees that are endangered or of concern in Canada, and those are only the species that have been identified (Government of Canada, 2018). Along with habitat loss, exposure to pesticides, diseases and pests, and poor nutrition (Ontario Ministry of Agriculture Food and Rural Affairs [OMAFRA], 2016; Woodcock et al., 2017), the commodification of Apis mellifera threatens and marginalizes native, wild bees through increased competition for food and disease transmission (City of Toronto, 2017; Graystock, Blane, McFrederick, Goulson, \& Hughes, 2016).

From an anthropocentric perspective, the loss of bees poses the obvious risks of threatening food supplies and associated financial losses. From an economic perspective, a future with compromised pollination from a lack of pollinating bees points to the need for pollination by hand, or innovative technology. The labor costs involved in hand pollination are significant, and hand pollination could result in an estimated 500 percent increase in production costs to US $\$ 90$ billion in the United States alone (Atkins \& Atkins, 2016). This potential increase in the cost of food production could cause an increase in food prices, creating a new form of food elitism. While the debate about the threats to bees goes on in earnest, one question remains conspicuously unanswered: "how can we possibly value, in monetary terms, the loss of a species" forever? (Atkins \& Atkins, 2016, p. 4).

Given the widespread use of pesticides in rural areas and the restrictive changes to pesticide use in urban areas, cities can provide a necessary habitat for wild bees, which include bumble bees and solitary bees (Woodcock et al., 2017). There is a relevant link between the literature on human well-being, contact with nature, and the kinds of urban environments that benefit bees. For example, along with providing a food source for wild bees, urban agriculture can benefit from increased yields with an increase in wild bee diversity (Colla, Willis, \& Packer, 2009). Recent research indicates that cities can provide important ecological landscapes as a refuge for wild bees (Baldock et al., 2015). This research shows the "biological value and ecological importance of cities" in this context (Hall et al., 2017, p. 27). Novel urban green space, such as green roofs, can benefit both people and pollinators, although their "value for biodiversity" requires further investigation (Colla et al., 2009; Tonietto et al., 2011).

Arguably, all pollination services by bees are informal economic activities, as there are no labor protections in place for either Apis mellifera or native species. With that said, pollination services contribute significantly to the market economy as outlined previously. In this way, services provided by bees have been divided into market services (formal) and non-market services (informal) (Hanley, Breeze, Ellis, \& Goulson, 2015). Contributions to the informal economy include the "aesthetic and cultural value of the wildflowers and garden plants which require pollination to sustain them" (p. 124). There are also the benefits pollinators provide to classroom learning, through an increase in outdoor classrooms and schoolyard gardens (Green \& Duhn, 2015; Winig \& Wooten, 2013). Additionally, there are the therapeutic benefits of gardens, such as hospital and long-term 
care gardens that rely largely on pollinators for their flowering plants (Gentry et al., 2015; Marcus $\&$ Barnes, 1995). There is a growing body of literature on the health and well-being benefits of urban nature, much of which is dependent on bees (Artmann et al., 2017; Guerry et al., 2015; Kaplan \& Kaplan, 1989; Mayer, Frantz, BruehlmanSenecal, \& Dolliver, 2009; Corvalan et al., 2005; Ulrich, 1984; Wolf \& Housley, 2013). Pollination dependent fruit and seed production also supplies important food sources for birds and other animals (Hanley et al., 2015).

Pollinators provide a unique opportunity for creating healthier whole-of-community urban spaces. The needs of pollinating bees require small actions that can yield large benefits for all community members (Hall et al., 2017). Few can argue against the need for a more integrated human-nature relationship that acknowledges and supports the intrinsic value of all parts of the ecosphere. Against a backdrop of cities, bees have been offered as a gateway and community bridge between human and nonhuman nature. In this new era, the Anthropocene, we must find "new ways of thinking and knowing, and innovative forms of action" (Gibson et al., 2015, p. i).

\section{Conclusion}

Bookchin (1992) called for an ecologized dialectic to "provide the basis for a living ecological ethics". Along with giving a more "liberatory meaning to vague words like interconnectedness," an ecologized dialectic can help us achieve "a conscious and ethical nature [and] ecological society" (Bookchin, 1992, para.63). Can we find examples of ways to achieve this vision? If "rather than seeing nature just as a passive recipient of human influence" we see it as "an agent that constrains and influences human beings and societies" how could this view radically alter how we interact with the rest of the biotic environment? (Arias-Maldonado, 2015, p. 10).

To build on the vision of an ecological society, we need to know more about "how place-specific physical environments can act as facilitators for, or barriers to, collective action" (Swyngedouw \& Kaika, 2008, p. 101). Classens (2015) identifies the failure "to adequately scrutinize the enmeshed character of nature and society" as a gap that could "ultimately contribute to untangling the potential and limits of urban gardens as sites of socio-political change" (p. 230). Blum (2016) has also identified a gap in understanding the relationship "among the sociocultural and physical-ecological variables of urban properties" (p. 14). MoraguesFaus \& Marsden (2017) call for a "far more inclusive and publicly engaging" approach to the "debates around food and nature" (p. 285). They suggest this be achieved by developing unorthodox techniques of creativity from different perspectives such as political ecology. Mitchell (2018) draws from Indigenous knowledge systems to suggest that what is needed is "repairing and strengthening" of broken "laws, agreements, treaties and protocols" between humans and nonhumans (p. 3). To this end, learning from, and engaging with, Indigenous knowledge systems could be a critical step towards "flourishing of future generations of multiple life forms" (Mitchell, 2018, p. 3).

A new urban WOC alternative is a radical approach in that it addresses power dynamics in and between all urban actants. Along with filling existing gaps, a WOC alternative is a fundamentally new way of being in common with the rest of the biotic community. If nature is everything and everywhere, and humans are just a part of the larger biotic community, then how can we interact with urban spaces to minimize negative impacts and allow for all biotic inhabitants to thrive? Our relationship and place in the natural world have changed over time, as have our impact and understanding of that impact (Bowden, 2017).

Leopold (1949) said, "A thing is right when it tends to preserve the integrity, stability, and beauty of the biotic community. It is wrong when it tends otherwise" (p. 262). It is important to understand the relationships between and among things- that is, how we interpret and interact with the world-if we are to exact any lasting positive changes. Two decades into the $21^{\text {st }}$ century, we are faced with unprecedented human-induced ecological crises. Given this fact, it is important to ask: "why is the imaginary of possible alternative urban natures still impotent" (Swyngedouw \& Kaika, 2008, p. 101). Examining the human-nature relationship through community-based, pollinator-friendly urban spaces 
is one way to engage, based on the premise that "to the degree that we come to understand other organisms, we will place a greater value on them, and on ourselves" (Wilson, 1984, p. 2). A WOC approach can help translate urban spaces into more integrated, productive, and inclusive communities and help to situate humans in more ecological terms to mitigate, and adapt to, the anthropogenic socio-ecological crises of the time.

\section{Acknowledgments}

The author would like to thank all the authors (cited and uncited) who came before and whose work inspired this piece. The author extends sincere thanks to Alison Blay-Palmer, Karen Landman, Irena Knezevic, and Robert McLeman for all their feedback, insights, and discussion following the writing of this paper. The author also thanks the reviewers for their thoughtful and valuable comments throughout the peer-review process.

\section{References}

Agyeman, J., \& McLaren, D. (2015). Sharing Cities: A case for truly smart and sustainable cities. Cambridge, MA: The MIT Press. https://doi.org/10.7551/mitpress/9780262029728.001.0001

Agyeman, J., \& McLaren, D. (2017). Sharing Cities. Environment: Science and Policy for Sustainable Development, 59(3), $22-27$. https://doi.org/10.1080/00139157.2017.1301168

Alkon, A. H., \& Agyeman, J. (2011). Cultivating food justice: Race, class, and sustainability. Cambridge MA: MIT Press.

Andersson, E., Barthel, S., \& Ahrné, K. (2007). Measuring social-ecological dynamics behind the generation of ecosystem services. Ecological Applications, 17(5), 1267-1278. https://doi.org/10.1890/06-1116.1

Arias-Maldonado, M. (2015). Environment and Society: Socionatural relations in the Anthropocene. New York: Springer. https://doi.org/10.1007/978-3-319-15952-2

Artmann, M., Bastian, O., \& Grunewald, K. (2017). Using the concepts of green infrastructure and ecosystem services to specify Leitbilder for compact and green cities_-The example of the landscape plan of Dresden. Sustainability, 9(2), 1-26. https://doi.org/10.3390/su9020198

Atkins, J., \& Atkins, B. (2016). The business of bees: An integrated approach to bee decline and corporate responsibility. Sheffield, UK: Greenleaf Publishing Limited. https://doi.org/10.4324/9781351283922

Baldock, K. C. R., Goddard, M. A., Hicks, D. M., Kunin, W. E., Mitschunas, N., Osgathorpe, L. M., ... Memmott, J. (2015). Where is the UK's pollinator biodiversity? The importance of urban areas for flower- visiting insects. Proceedings of the Royal Society B, 282(1803). https://doi.org/10.1098/rspb.2014.2849

Barua, M., Gurdak, D., Ahmed, R. A., \& Tamuly, J. (2012). Selecting flagships for invertebrate conservation. Biodiversity and Conservation, 21(6), 1457-1476. https://doi.org/10.1007/s10531-012-0257-7

Becker, K. F. (2004). The Informal Economy: fact finding study. Swedish International Development Cooperation Agency. Retrieved February 2016 from http://www.rrojasdatabank.info/sida.pdf

Bennett, J. (2010). Vibrant Matter: A political ecology of things. Durham, NC: Duke University Press. https://doi.org/10.1215/9780822391623

Bennet, M., \& Teague, D. (1999). The nature of cities: ecocriticism and urban environments. Tucson: University of Arizona Press.

Bird, G. (2016). Containing Community: From Political Economy to Ontology in Agamben, Esposito, and Nancy. Albany: State University of New York Press.

Blaikie, P., \& Brookfield, H. (Eds.). (1987). Land degradation and society. London: Methuen.

Blasdel, A. (2017, June 15). 'A reckoning for our species': The philosopher prophet of the Anthropocene. The Guardian. Retrieved from https://www.theguardian.com/world/2017/jun/15/timothy-morton-anthropocene-philosopher

Blay-Palmer, A. (Ed.). (2016). Imagining sustainable food systems: Theory and practice. London: Routledge. https://doi.org/10.4324/9781315587905

Blay-Palmer, A., Sonnino, R., \& Custot, J. (2016). A food politics of the possible? Growing sustainable food systems through networks of knowledge. Agriculture and Human V alues, 33(1), 27-43. https://doi.org/10.1007/s10460-015-9592-0

Blecha, J., \& Leitner, H. (2014). Reimagining the food system, the economy, and urban life: New urban chicken-keepers in US cities. Urban Geography, 35(1), 86-108. https://doi.org/10.1080/02723638.2013.845999 
Blum, J. (Ed.). (2016). Urban horticulture: Ecology, landscape, and agriculture. New York: Apple Academic Press. https://doi.org/10.1201/9781315366098

Boelsen-Robinson, T., Peeters, A., Beauchamp, A., Chung, A., Gearon, E., \& Backholer, K. (2015). A systematic review of the effectiveness of whole-of-community interventions by socioeconomic position. Obesity Reviews, 16(9), 806816. https://doi.org/10.1111/obr.12297

Bookchin, M. (1992). A philosophical naturalism. In The philosophy of social ecology: Essays on dialectical naturalism (2nd Ed.). Montreal: Black Rose Books. Retrieved from http://dwardmac.pitzer.edu/Anarchist Archives/bookchin/philosonatural.html

Bowden, G. (2017). An environmental sociology for the Anthropocene. Canadian Review of Sociology/Revue canadienne de sociologie, 54(1), 48-68. https://doi.org/10.1111/cars.12138

Braun, B., \& Castree, N. (Eds). (1998). Remaking reality: Nature at the millennium. London: Routledge.

Braun, B. (2005). Environmental issues: Writing a more-than-human urban geography. Progress in Human Geography, 29(5), 635-650. https://doi.org/10.1191/0309132505ph574pr

Brown, L. R., Flavin, C., French, H., Abramovitz, J., Bright, C., Gardiner, G., .. Starke, L. (1997). State of the world: A Worldwatch Institute Report on progress toward a sustainable society. New York: W. W. Norton.

Cadieux, K. V., \& Slocum, R. (2015). What does it mean to do food justice? Journal of Political Ecology, 22(1), 1-26. https://doi.org/10.2458/v22i1.21076

Canales, M. (2000). Othering: Toward an understanding of difference. Advances in Nursing Science, 22(4), 16-31. https://doi.org/10.1097/00012272-200006000-00003

Caniglia, B. S., Vallee, M., \& Frank, B. (Eds.). (2016). Resilience, environmental justice and the city. London: Routledge. https://doi.org/10.4324/9781315652054

Carr, M. (2004). Bioregionalism and civil society: Democratic challenges to corporate globalism. Vancouver: UBC Press.

Castree, N. (2014a). The Anthropocene and geography I: The back story. Geography Compass, 8(7), 436-449. https://doi.org/10.1111/gec3.12141

Castree, N. (2014b). The Anthropocene and the environmental humanities: Extending the conversation. Environmental Humanities, 5(1), 233-260. https://doi.org/10.1215/22011919-3615496

Castree, N. (2014c). Making sense of nature. Abingdon, Oxon: Routledge. https://doi.org/10.4324/9780203503461

Castree, N., \& Braun, B. (Eds.). (2001). Social nature theory, practice, and politics. Malden, MA: Blackwell Publishers.

Chaplin-Kramer, R., Dombeck, E., Gerber, J., Knuth K. A., Mueller, N. D., Mueller, M., ... Klein, A.-M. (2014). Global malnutrition overlaps with pollinator-dependent micronutrient production. Proceedings of the Royal Society B, 281(1794). https://doi.org/10.1098/rspb.2014.1799

Chen, M. A. (2007). Rethinking the informal economy: Linkages with the formal economy and the formal regulatory environment (Working Paper No. 46). United Nations, Department of Economic and Social Affairs. Retrieved April 2016 from http://www.un.org/esa/desa/papers/2007/wp46_2007.pdf

Chen, M. A. (2012). The informal economy: Definitions, theories, and policies (Working Paper No. 1). Women in Informal Employment: Globalizing and Organizing. Retrieved February 2016 from http://wiego.org/sites/wiego.org/files/publications/files/Chen WIEGO WP1.pdf

Cianchi, J. (2015). Radical environmentalism: Nature, identity and more-than-human agency. London: Palgrave Macmillan. https://doi.org/10.1057/9781137473783

City of Toronto. (2017). Toronto pollinator protection strategy: Draft priorities and actions. Retrieved from https://www.toronto.ca/wp-content/uploads/2017/11/9819-Toronto-Pollinator-Strategy-Booklet-DraftPriorities-and-Actions-2017.pdf

Classens, M. (2015). The nature of urban gardens: Toward a political ecology of urban agriculture. Agriculture and Human Values, 32(2), 229-239. https://doi.org/10.1007/s10460-014-9540-4

Colla, S., Willis, E., \& Packer, L. (2009). Can green roofs provide habitat for urban bees? Cities and the Environment, 2(1), 4-12. https://doi.org/10.15365/cate.2142009

Corvalan, C., Hales, S., McMichael, A., Butler, C., Campbell-Lendrum, D., Confalonieri, U., ... Younes, M. (2005). Ecosystems and human well-being: Synthesis. Millennium Ecosystem Assessment. Washington, D.C.: Island Press 
Cronon, W. (1991). Nature's metropolis: Chicago and the Great West. New York: W. W. Norton.

Cronon, W. (Ed). (1995). Uncommon ground: Toward reinventing nature. New York: W. W. Norton.

Crutzen, P., \& Stoermer, E. (2000). The Anthropocene. Global Change Newsletter, 41, 17-18.

Cunsolo, A., \& Landman, K. (Eds.). (2017). Mourning nature: Hope at the heart of ecological loss and grief. Montreal: McGillQueen's University Press. https://doi.org/10.2307/j.ctt1w6t9hg

Dahlberg, K. (1994). A transition from agriculture to regenerative food systems. Futures, 26(2), 170-179. https://doi.org/10.1016/0016-3287(94)90106-6

Deveau, D. (2016, June 2). Urban beekeeping takes off as plight of the honeybee wins public attention. Financial Post. Retrieved from http://business.financialpost.com/entrepreneur/growth-strategies/urban-beekeeping-takes-off-asplight-of-the-honeybee-wins-public-attention/wcm/54e4e4b8-8d46-4b03-ad8e-323474045994

de Zeeuw, H., \& Drechsel, P. (Eds.). (2015). Cities and agriculture: Developing resilient urban food systems. New York: Routledge.

Dube, L., Bechara, A., Dagher, A., Drewnowski, A., LeBel, J., James, P., \& Yada, R. Y. (2010). Obesity prevention: The role of brain and society on individual behavior. San Diego, CA: Academic Press.

Ellis, E. C., \& Ramankutty, N. (2008). Putting people in the map: Anthropogenic biomes of the world. Frontiers in Ecology and the Environment, 6(8), 439-447. https://doi.org/10.1890/070062

Ellis, E. C., Klein Goldewijk, K., Siebert, S., Lightman, D., \& Ramankutty, N. (2010). Anthropogenic transformation of the biomes, 1700 to 2000. Global Ecology and Biogeography, 19(5), 589-606. https://doi.org/10.1111/j.1466$\underline{8238.2010 .00540 . x}$

Ellis, E. C. (2013). Sustaining biodiversity and people in the world's anthropogenic biomes. Current Opinion in Environmental Sustainability, 5(3-4), 368-372. https://doi.org/10.1016/j.cosust.2013.07.002

Emmett, R. S., \& Nye, D. E. (2017). The environmental bumanities: A critical introduction. Cambridge, MA: The MIT Press. https://doi.org/10.7551/mitpress/10629.001.0001

Environment Canada, Federal-Provincial-Territorial Task Force on the Importance of Nature to Canadians. (2000). The importance of nature to Canadians: The economic significance of nature-related activities. Retrieved from http://publications.gc.ca/collections/Collection/En47-312-2000E.pdf

Erickson, M. S. (2012). Restorative garden design: Enhancing wellness through healing spaces. Journal of Art and Design Discourse, (2), 89-101.

Ehrlich, P. (1968). The population bomb. New York: Ballantine Books.

Ewart-Pierce, E., Mejía Ruiz, M. J., \& Gittelsohn, J. (2016). "Whole-of-community" obesity prevention: A review of challenges and opportunities in multilevel, multicomponent interventions. Current Obesity Reports, 5(3), 361-374. https://doi.org/10.1007/s13679-016-0226-7

Food and Agriculture Organization [FAO] of the United Nations, \& Resource Centres on Urban Agriculture and Food Security [RUAF] Foundation. (2015). A vision for city region food systems: Building sustainable and resilient city regions. Retrieved from http://www.fao.org/3/a-i4789e.pdf

Federal Emergency Management Agency [FEMA]. (2011). A whole community approach to emergency management: Principles, themes, and pathways for action. Retrieved from https://www.fema.gov/media-library-data/201307261813-25045-0649/whole_community_dec2011____.pdf

Fincher, R., \& Iveson, K. (2015). Conviviality as an ethic of care in the city. In K. Gibson, D. B. Rose, \& R. Fincher, (Eds.), Manifesto for Living in the Anthropocene (pp. 23-27). Brooklyn, New York: Punctum Books.

Fraser, E. D. G. (2013). Coping with food crises: Lessons from the American Dust Bowl on balancing local food, agro technology, social welfare, and government regulation agendas in food and farming systems. Global Environmental Change, 23(6), 1662-1672. https://doi.org/10.1016/j.gloenvcha.2013.09.001

Friedmann, H. (2005). From colonialism to green capitalism: Social movements and emergence of food regimes. In F. H. Buttel, \& P. McMichael (Eds.), New directions in the sociology of global development (pp. 227-264). Emerald Group.

Foucault, M. (1978). The history of sexuality: An introduction. New York: Random House.

Gaston, K. J. (2010). Urban ecology. Cambridge: Cambridge University Press. https://doi.org/10.1017/CBO9780511778483 
Gentry, B., Anderson, J. E., Krause, D. R., Tucker, W. C., \& Tuddenham, K. A. (2015). Improving human health by increasing access to natural areas: Linking research to action at scales (Report No. 31). Yale Program on Strategies for the Future of Conservation. Retrieved from http://environment.yale.edu/publication-series/documents/downloads/ag/Berkley-2014-Workshop.pdf

Gibson, K., Rose, D., \& Fincher, R. (Eds.). (2015). Manifesto for living in the Anthropocene. Brooklyn, NY: Punctum Books.

Godfrey, P. C. (2011). Toward a theory of the informal economy. The Academy of Management Annals, 5(1), $231-277$. https://doi.org/10.5465/19416520.2011.585818

Government of Canada. (2018). Species at risk: The act, the accord, and the funding programs. Retrieved October 2018 from https://www.canada.ca/en/environment-climate-change/services/species-risk-act-accord-funding.html

Graystock, P., Blane, E. J., McFrederick, Q. S., Goulson, D., \& Hughes, W. O. H. (2016). Do managed bees drive parasite spread and emergence in wild bees? International Journal for Parasitology: Parasites and Wildlife, 5(1), 64-75. https://doi.org/10.1016/j.ijppaw.2015.10.001

Green, M., \& Duhn, I. (2015). The force of gardening: Investigating children's learning in a food garden. Australian Journal of Environmental Education, 31(1), 60-73. https://doi.org/10.1017/aee.2014.45

Grewal, S. S., \& Grewal, P. S. (2012). Can cities become self-reliant in food? Cities, 29(1), 1-11. https://doi.org/10.1016/j.cities.2011.06.003

Guerry, A. D., Polasky, S., Lubchenco, J., Chaplin-Kramer, R., Daily, G. C., Griffen, R., ... Vira, B. (2015). Natural capital and ecosystem services informing decisions: From promise to practice. Proceedings of the National Academy of Sciences of the United States of America, 112(24), 7348-7355. https://doi.org/10.1073/pnas.1503751112

Guthman, J. (2004). Agrarian dreams: The paradox of organic farming in California. Berkeley: University of California Press.

Hall, D. M., Camilo, G. R., Tonietto, R. K., Ollerton, J., Ahrné, K., Arduser, M., .. Threlfall, C. G. (2017). The city as a refuge for insect pollinators. Conservation Biology, 31(1), 24-29. https://doi.org/10.1111/cobi.12840

Hanley, N., Breeze, T. D., Ellis, C., \& Goulson, D. (2015). Measuring the economic value of pollination services: Principles, evidence and knowledge gaps. Ecosystem Services, 14, 124-132. https://doi.org/10.1016/i.ecoser.2014.09.013

Haraway, D. (1991). A cyborg manifesto: Science, technology, and socialist-feminism in the late twentieth century. In D. Haraway, Simians, Cyborgs and Women: The Reinvention of Nature (pp.149-181). New York: Routledge.

Hart, K. (1973). Informal income opportunities and urban employment in Ghana. The Journal of Modern African Studies, 11(1), 61-89. https://doi.org/10.1017/S0022278X00008089

Harvey, D. (1996). Justice, nature and the geography of difference. Cambridge, MA: Blackwell.

Harvey, D. (2003). The right to the city. International Journal of Urban and Regional Research, 27(4), 939-941. https://doi.org/10.1111/j.0309-1317.2003.00492.x

Harvey, D. (2012). Rebel cities: From the right to the city to the urban revolution. London: Verso.

Hassan, R., Scholes, R., \& Ash, N. (Eds.). (2005). Ecosystems and buman well-being: current state and trends, Volume 1. Findings on the Conditions and Trends Working Group of the Millennium Ecosystem Assessment. Washington, D.C.: Island Press. Retrieved from https://www.millenniumassessment.org/documents/document.766.aspx.pdf

Hawken, P., Lovins, A. B., \& Lovins, L. H. (2013). Natural capitalism: The next industrial revolution. London: Routledge.

Hébert, K., \& Mincyte, D. (2014). Self-reliance beyond neoliberalism: Rethinking autonomy at the edges of empire. Environment and Planning D: Society and Space, 32(2), 206-222. https://doi.org/10.1068/d6312

Heinberg, R. (2010). Peak everything: Waking up to the century of declines. Gabriola Island: New Society.

Heynen, N., Kaika, M., \& Swyngedouw, E. 2006). Urban political ecology: Politicizing the production of urban natures. In N. Heynen, M. Kaika, \& E. Swyngedouw (Eds.), In the nature of cities: Urban political ecology and the politics of urban metabolism. London: Routledge.

Hicks, D. M., Ouvrard, P., Baldock, K. C. R., Baude, M., Goddard, M., Kunin, W. E., ... Stone, G. N. (2016). Food for pollinators: Quantifying the nectar and pollen resources of urban flower meadows. PLoS One, 11(6), 1-37. https://doi.org/10.1371/journal.pone.0158117

Hussain, A. (2011). The informal economy: Here to stay? International Trade Forum, 4, 22-23. 
Journal of Agriculture, Food Systems, and Community Development

ISSN: 2152-0801 online

https://www.foodsystemsjournal.org

Intergovernmental Science-Policy Platform on Biodiversity and Ecosystem Services [IPBES]. (2016). The assessment report on pollinators, pollination and food production. Retrieved October 25, 2018, from https://www.ipbes.net/assessmentreports/pollinators

Jackson, J. (Ed.). (2012). The Routledge handbook of language and intercultural communication. London: Routledge. https://doi.org/10.4324/9780203805640

Jacobs, J. (1961). The death and life of great American cities. New York: Vintage Books.

Jaffee, D. (2007). Industrialization and conflict in America: 1840-1875. In Heilbrunn Timeline of Art History. New York: The Metropolitan Museum of Art. Retrieved from http://www.metmuseum.org/toah/hd/indu/hd indu.htm

Kamrava, M. (2004). The semi-formal sector and the Turkish political economy. British Journal of Middle Eastern Studies, 31(1), 63-87. https://doi.org/10.1080/1353019042000203449

Kaplan, R., \& Kaplan, S. (1989). The experience of nature: A psychological perspective. New York: Cambridge University Press.

Kitchen, L., \& Marsden, T. (2011). Constructing sustainable communities: A theoretical exploration of the bio-economy and eco-economy paradigms. Local Environment, 16(8), 753-769. https://doi.org/10.1080/13549839.2011.579090

Klein, A.-M., Vaissière, B. E., Cane, J. H., Steffan-Dewenter, I., Cunningham, S. A., Kremen, C., \& Tscharntke, T. (2007). Importance of pollinators in changing landscapes for world crops. Proceedings of the Royal Society of London B: Biological Sciences, 274(1608), 303-313. https://doi.org/10.1098/rspb.2006.3721

Kosek, J. (2011). The natures of the beast: On the new uses of the honeybee. In R. Peet, P. Robbins, \& M. Watts (Eds.), Global Political Ecology (pp. 242-266). New York: Routledge.

Kull, C. A., Arnauld de Sartre, X., \& Castro-Larranaga, M. (2015). The political ecology of ecosystem services. Geoforum, 61, 122-134. https://doi.org/10.1016/j.geoforum.2015.03.004

Latour, B. (1993). We have never been modern (C. Porter \& H. Hempstead, Trans.). London: Harvester Wheatsheaf.

Lefebvre, H. (1966). Writings on cities. Malden, MA: Blackwell.

Leopold, A. (1949). A Sand County almanac and sketches here and there. New York: Oxford University Press.

Lorenz, S., \& Stark, K. (2015). Saving the honeybees in Berlin? A case study of the urban beekeeping boom. Environmental Sociology, 1(2), 116-126. https://doi.org/10.1080/23251042.2015.1008383

Marcus, C. C., \& Barnes, M. (1995). Gardens in healthcare facilities: Uses, therapeutic benefits, and design recommendations. Martinez, CA: The Center for Health Design. Retrieved from https://www.healthdesign.org/sites/default/ files/Gardens $\% 20 \mathrm{in} \% 20 \mathrm{HC} \% 20 \mathrm{Facility} \% 20 \mathrm{Visits}$.pdf

Marcus, C. C., \& Sachs, N. A. (2014). Therapeutic landscapes: An evidence-based approach to designing bealing gardens and restorative outdoor spaces. Hoboken, N.J.: John Wiley \& Sons.

Mare, S. (n.d.). Conservation and preservation. Retrieved from http://www.ecoca.ro/meteo/tutorial/Sustainability/Older/Conservation and Preservation.html

Marsden, T. (2012). Third natures? Reconstituting space through place-making strategies for sustainability. International Journal of Sociology of Agriculture and Food, 19(2), 257-274.

Marx, K. (1867). Capital: A critique of political economy. Volume 1 (S. Moore \& E. Aveling, Trans.). Moscow: Progress Publishers. Retrieved from https://www.marxists.org/archive/marx/works/download/pdf/Capital-Volume-I.pdf

Matteson, K., \& Langellotto, G. A. (2010). Determinates of inner city butterfly and bee species richness. Urban Ecosystems, 13(3), 333-347. https://doi.org/10.1007/s11252-010-0122-y

Mayer, S. F., Frantz, C. M., Bruehlman-Senecal, E., \& Dolliver, K. (2009). Why is nature beneficial? The role of connectedness to nature. Environment and Behavior, 41(5), 607-643. https://doi.org/10.1177/0013916508319745

McLaren, D. (2015). Sharing cities: An urban commons for the digital age [Lecture]. Retrieved from https://opencommons.linz.at/wp-content/uploads/2015/04/Sharing-Cities-Linz-final.pdf

McLaren, D., \& Agyeman, J. (2015). Sharing cities: A case for truly smart and sustainable cities. Cambridge: The MIT Press. https://doi.org/10.7551/mitpress/9780262029728.001.0001

Meadows, D. H., Meadows, D. L., Randers, J., \& Behrens, W. W., III. (1972). The limits to growth; A report for the Club of Rome's project on the predicament of mankind. New York: Universe Books. https://doi.org/10.1349/ddlp.1

Meadows, D., Randers, J., \& Meadows, D. (2004). Limits to growth: The 30-year update. White River Junction, VT: Chelsea Green Publishing. 
Merchant, C. (1995). Reinventing Eden: Western culture as a recovery narrative. In W. Cronon (Ed.), Uncommon ground: Toward reinventing nature (pp. 132-159). New York: W. W. Norton.

Mitchell, A. (2018). Revitalizing laws, (re)-making treaties, dismantling violence: Indigenous resurgence against 'the sixth mass extinction.'. Social and Cultural Geography, 19, 1-16. https://doi.org/10.1080/14649365.2018.1528628

Moragues-Faus, A., \& Marsden, T. (2017). The political ecology of food: Carving 'spaces of possibility' in a new research agenda. Journal of Rural Studies, 55, 275-288. https://doi.org/10.1016/j.jrurstud.2017.08.016

Mountz, A. (2009). The other. In C. Gallaher (Ed.), Key concepts in political geography (pp. 328-338). London: SAGE. https://doi.org/10.4135/9781446279496.n35

Muir, J., \& Cronon, W. (1997). John Muir: Nature writings: The story of my boyhood and youth. My first summer in the Sierra. The mountains of California. Stickeen. Essays. New York: Library of America.

Myers, J. (2005). Converging stories: Race, ecology, and environmental justice in American literature. Athens: University of Georgia Press.

Naess, A. (1989). Ecology, community and lifestyle: Outline of an ecosophy. Cambridge: Cambridge University Press. https://doi.org/10.1017/CBO9780511525599

National Park Service [NPS]. (2015). Lesson plan: Conservation vs. preservation and the National Park Service. Retrieved from https://www.nps.gov/teachers/classrooms/conpres.htm

Ollerenshaw, A. (2012). Literacy Trails: A whole-of-community program to encourage literacy and numeracy for children in preschool and early primary. Australasian Journal of Early Childhood, 37(3), 147-153. https://doi.org/10.1177/183693911203700319

Ollerton, J., Winfree, R., \& Tarrant, S. (2011). How many flowering plants are pollinated by animals? Oikos, 120(3), 321-327. https://doi.org/10.1111/j.1600-0706.2010.18644.x

Ontario Ministry of Agriculture Food and Rural Affairs [OMAFRA]. (2016). Pollinator Health Action Plan. Retrieved from https://www.ontario.ca/page/pollinator-health

Pfiffner, L., \& Muller, A. (2016). Wild bees and pollination (C. Hay, Trans.). Research Institute of Organic Agriculture. Retrieved from http://ebionetwork.julius-kuehn.de/dokumente/upload/FiBL wildbee pfiffner2016.pdf

Plumwood, V. (2002). Environmental culture: The ecological crisis of reason. New York: Routledge.

Plumwood, V. (2007). A review of Deborah Bird Rose's 'Reports from a wild country: Ethics for cecolonisation.' Australian Humanities Review, 42. Retrieved from http://australianhumanitiesreview.org/2007/08/01/a-review-ofdeborah-bird-roses-reports-from-a-wild-country-ethics-for-decolonisation/

Plumwood, V. (2009). Nature in the active voice. Australian Humanities Review, 46, 113-129. https://doi.org/10.22459/AHR.46.2009.10

Portes, A., \& Sassen-Koob, S. (1987). Making it underground: Comparative material on the informal sector in Western market economies. American Journal of Sociology, 93(1), 30-61. https://doi.org/10.1086/228705

Rademacher, A. (2015). Urban political ecology. Annual Review of Anthropology, 44, 137-152. https://doi.org/10.1146/annurev-anthro-102214-014208

Robbins, P. (2012). Political ecology: A critical introduction. West Sussex: John Wiley \& Sons.

Rose, D. B., \& Robin, L. (2004). The ecological humanities in action: An invitation. Australian Humanities Review, 31-32. Retrieved from http://australianhumanitiesreview.org/2004/04/01/the-ecological-humanities-in-action-aninvitation/

Rose, D. B., van Dooren, T., Chrulew, M., Cooke, S., Kearnes, M., \& O'Gorman, E. (2012). Thinking through the environment, unsettling the humanities. Environmental Humanities, 1(1), 1-5. https://doi.org/10.1215/22011919$\underline{3609940}$

RUAF Foundation (n.d.). Urban agriculture: What and why? Retrieved from http://www.ruaf.org/urban-agriculturewhat-and-why

Said, E. W. (1978). Orientalism. New York: Vintage.

Seeds of Diversity. (n.d.). Pollination Canada. Retrieved from https://www.seeds.ca/pollination 
Sheffield, C. S., Heron, J., Gibbs, J., Onuferko, T. M., Oram, R., Best, L., .. Rowe, G. (2017). Contribution of DNA barcoding to the study of the bees (Hymenoptera: Apoidea) of Canada: Progress to date. The Canadian Entomologist, 149(6), 736-754. https://doi.org/10.4039/tce.2017.49

Shephard, M., Vaughan, M., \& Black, S. H. (2008). Pollinator friendly parks: How to enhance parks, gardens, and other greenspaces for native pollinator insects. The Xerces Society for Invertebrate Conservation. Retrieved from http://www.xerces.org/wp-content/uploads/2009/05/pollinator_friendly_parks_21ed_xerces_society.pdf

Shoemaker, C. (Ed.). (2006). Proceedings of the International Symposium on Horticultural Practices and Therapy for Human Well-Being: International Society for Horticultural Science. The Netherlands: ISHS Secretariat.

Smith, N. (2009). Nature as accumulation strategy. Socialist Register, 43, 16-36. Retrieved from https://socialistregister.com/index.php/srv/article/view/5856

Soper, K. (1995). What is nature?: Culture, politics and the non-human. Oxford: Blackwell.

Spash, C. L. (2015). Bulldozing biodiversity: The economics of offsets and trading-in nature. Biological Conservation, 192, 541-551. https://doi.org/10.1016/j.biocon.2015.07.037

Suryanarayanan, S., \& Kleinman, D. L. (2016). Vanishing bees: Science, politics, and honeybee health. New Brunswick, N.J.: Rutgers University Press.

Swyngedouw, E. (1996). The city as hybrid: On nature, society, and cyborg urbanization. Capitalism Nature Socialism, 7(2), 65-80. https://doi.org/10.1080/10455759609358679

Swyngedouw, E. (1999). Modernity and hybridity: Nature, regeneracionismo, and the production of the Spanish waterscape, 1890-1930. Annals of the Association of American Geographers, 89(3), 443-465. https://doi.org/10.1111/0004$\underline{5608.00157}$

Swyngedouw, E. (2006) Metabolic urbanization: The making of cyborg cities. In N. C. Heynen, M. Kaika, \& E. Swyngedouw (Eds.), The nature of cities: Urban political ecology and the politics of urban metabolism (pp. 21-40). Oxford: Routledge.

Swyngedouw, E., \& Kaika, M. (2008). The environment of the city or the urbanization of nature. In G. Bridge \& S. Watson (Eds.), Companion to the city. Malden, MA: Blackwell.

Thone, F. (1935). Nature rambling: We fight for grass. The Science Newsletter, 27(717), 14. https://doi.org/10.2307/3911681

Tonietto, R., Fant, J., Ascher, J., Ellis, K., \& Larkin, D. (2011). A comparison of bee communities of Chicago green roofs, parks and prairies. Landscape and Urban Planning, 103(1), 102-108. https://doi.org/10.1016/j.landurbplan.2011.07.004

Ulrich, R. S. (1984). View through a window may influence recovery from surgery. Science, 224(4647), 420-421. https://doi.org/10.1126/science.6143402

United Nations, Department of Economic and Social Affairs, Population Division. (2014). World urbanization prospects: The 2014 Revision, Highlights. Retrieved from https://esa.un.org/unpd/wup/publications/files/wup2014highlights.Pdf

United Nations, Habitat III Secretariat. (2017). New urban agenda. Retrieved from http://habitat3.org/wpcontent/uploads/NUA-English.pdf

United States Environmental Protection Agency [EPA]. (2018). Colony Collapse Disorder. Retrieved April 2019 from https://www.epa.gov/pollinator-protection/colony-collapse-disorder

University of Leicester. (2016). Media note: Anthropocene Working Group (AWG). Retrieved from http://www2.le.ac.uk/offices/press/press-releases/2016/august/media-note-anthropocene-working-group-awg

van Dooren, T. (2016). What is nature? [Video file]. University of New South Wales, Sydney Australia. Retrieved from https://www.futurelearn.com/courses/remaking-nature/0/steps/16721

Waliczek, T. M., \& Zajicek, J. M. (2016). Urban horticulture. Boca Raton, FL: CRC Press. https://doi.org/10.1201/b19618

Whatmore, S. (2002). Hybrid geographies: Natures cultures spaces. London: SAGE.

Whatmore, S. (2006). Materialist returns: Practising cultural geography in and for a more-than- human world. Cultural Geographies, 13(4), 600-609. https://doi.org/10.1191/1474474006cgj377oa 
White, R. J. (2009). Explaining why the non-commodified sphere of mutual aid is so pervasive in the advanced economies. International Journal of Sociology and Social Policy, 29(9/10), 457-472. https://doi.org/10.1108/01443330910986252

Widener, M. J. (2018). Spatial access to food: Retiring the food desert metaphor. Physiology \& Behavior, 193(B), 257-260. https://doi.org/10.1016/j.physbeh.2018.02.032

Williams, R. (1980). Ideas of nature. In Problems in materialism and culture: Selected essays (pp. 67-84). London: Verso.

Williams, C., \& Windebank, J. (2003). Alternative employment spaces. In A. Leyshon, R. Lee, \& C. Williams (Eds.), Alternative economic spaces (pp. 128-150), London SAGE. https://doi.org/10.4135/9781446220825.n6

Wilson, E. O. (1984). Biophilia. Cambridge, MA: Harvard University Press.

Winig, B., \& Wooten, H. (2013). Dig, eat, and be healthy: A guide to growing food on public property. Change Lab Solutions. Retrieved from https://www.changelabsolutions.org/publications/dig-eat-be-healthy

Winson, A. (1992). The intimate commodity: Food and the development of the agro-industrial complex in Canada. Toronto: Garamond.

Wolch, J., \& Emel, J. (Eds.). (1998). Animal geographies: Place, politics, and identity in the nature-culture borderlands. New York: Verso.

Wolf, E. (1972). Ownership and political ecology. Anthropological Quarterly, 45(3), 201-205. https://doi.org/10.2307/3316532

Wolf, E. R. (1982). Europe and the people without history. Berkeley: University of California Press.

Wolf, K., \& Housley, E. (2013). Research brief: Feeling stressed? Take a time out in nature. Nature Sacred. Retrieved from http://naturesacred.org/wp-content/uploads/2014/05/TKF StressReport-v5 SinglePages.pdf

Woodcock, B. A., Bullock, J. M., Shore, R. F., Heard, M. S., Pereira, M. G., Redhead, J., ... Pywell, R. F. (2017). Country-specific effects of neonicotinoid pesticides on honey bees and wild bees. Science, 356(6345), $1393-1395$. https://doi.org/10.1126/science.aaa1190

Wright, L. (2017, March 12). The rise and rise of urban beekeeping. BBC News. Retrieved from http://www.bbc.com/news/uk-england-38227113

Yang, S. (2006, October 25). Pollinators help one-third of world's crop production, says new study. UCBerkley News. Retrieved from https://www.berkeley.edu/news/media/releases/2006/10/25_pollinator.shtml

Zimmer, A. (2010). Urban political ecology: Theoretical concepts, challenges, and suggested future directions. Erdkunde, 64(4), 343-354. https://doi.org/10.3112/erdkunde.2010.04.04 